\title{
Effect of Depth of Water Table on Yields of Two Cultivars of Sweet Potatoes ${ }^{1,2}$
}

\author{
Servando Silva and Heber Irizarry ${ }^{3}$ \\ ABSTRACT
}

\begin{abstract}
Sweet potatoes of the yellow-fleshed Gem cultivar produced 6.7, 13.4 and $33.0 \mathrm{t} / \mathrm{ha}$ of marketable tubers, and those of the white-fleshed Miguela cultivar produced $1.8,13.4$ and $21.4 \mathrm{t} / \mathrm{ha}$, when the depth to the water table in a Fluventic Hapludolls in lysimeter tanks was maintained at 15,30 and 45 $\mathrm{cm}$, respectively.
\end{abstract}

\section{INTRODUCTION}

Studies on the performance of sweet potato cultivars (Ipomoea batatas (L.) Lam.) have been carried out on various soil types and locations in Puerto Rico (1, 2, 3, 6, 8, 9). The effects of planting dates (4) and fertilizer applications on yields of sweet potatoes $(5,7,10)$ have also been studied in Puerto Rico. However, no information is available on the effect of water table levels on sweet potato yields in Puerto Rico or elsewhere in the tropics. This information is useful in designing drainage systems and in selecting areas best suited to this crop.

This study was conducted to determine the effect of the water table level on the yield of two cultivars of sweet potatoes.

\section{MATERLALS AND METHODS}

The experiment was conducted in Rio Piedras at an elevation of about $30 \mathrm{~m}$. Average annual temperature is about $26^{\circ} \mathrm{C}$ and average monthly variation is about $5^{\circ} \mathrm{C}$. Annual rainfall is about 2,000 $\mathrm{mm}$. The winter months are fairly dry with heavy rains in the fall.

Twenty-four concrete lysimeter tanks ( $1.2 \mathrm{~m}$ wide, $2.4 \mathrm{~m}$ long and 45 $\mathrm{cm}$ deep) were used in the experiment. The lysimeters were filled with Toa clay loam (Fluventic Hapludolls), which was allowed to settle for 2 months to its normal bulk density (about 1.3). The soil has a $\mathrm{pH}$ of 5.8 and $3.8 \%$ of organic matter. The exchange capacity is $22 \mathrm{meq} / 100 \mathrm{~g}$ of soil with 14 meq of bases/100 g of soil.

Vines about $50 \mathrm{~cm}$ long of the Gem (yellow-fleshed) and Miguela (white-fleshed) cultivars were used as propagating material. These vines were planted $80 \mathrm{~cm}$ apart in furrows. Fertilizer was applied at the rate of

${ }^{1}$ Manuscript submitted to Editorial Board January 22, 1980.

${ }^{2}$ This paper covers work carried out cooperatively between Agricultural Research, Science and Education Administration, USDA, and the Agricultural Experiment Station, Mayagüez Campus, University of Puerto Rico, Río Piedras P.R.

${ }^{3}$ Research Technician and Research Horticulturist, Agricultural Research Science and Education Administration, USDA, Río Piedras, P.R., respectively. 
$500 \mathrm{~kg}$ of $10-5-20 / \mathrm{ha}$ at planting and 3 months later. The sweet potatoes were planted in September 1978, and the tubers were harvested when the crop was 6 months old. The plants were irrigated weekly, except when rainfall was abundant.

The treatments, initiated 2 weeks after planting, consisted of maintaining a free water table at the 15,30 , and $45 \mathrm{~cm}$ soil depth under both sweet

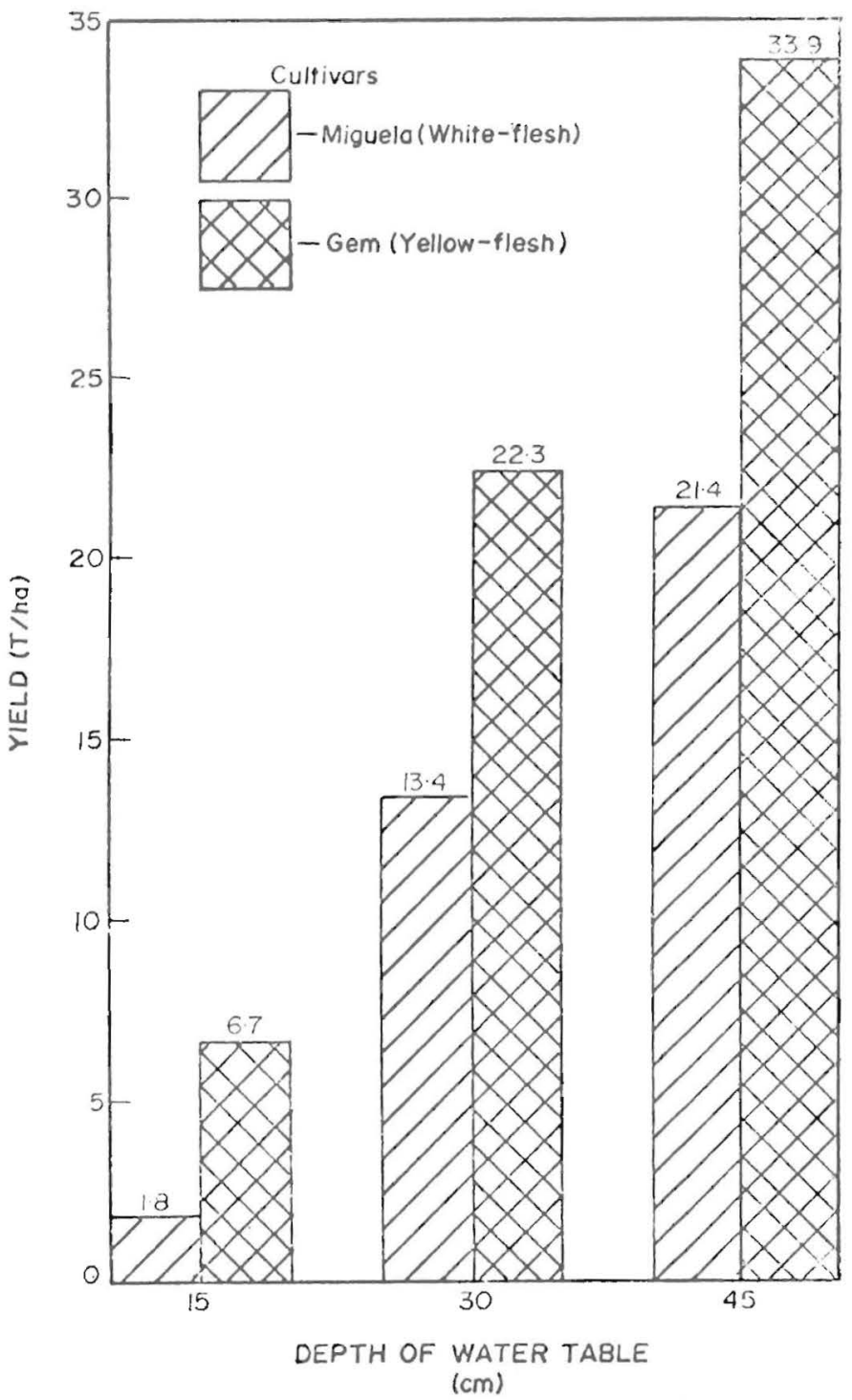

FIG. 1.-Effect of depth of water table on yields of two sweet potato cultivars. 
potato cultivars. The water table was maintained at the desired levels in the lysimeter tanks by adjusting the level of water in connecting open tanks. The two cultivars and three water table levels were arranged in a randomized complete block design with four replications.

\section{RESULTS AND DISCUSSION}

Both sweet potato cultivars had vigorous growth at all three water levels; however, marketable yields were significantly affected by water table depths.

Figure 1 shows that yields of the Gem cultivar increased from 6.7 to $33.9 \mathrm{t} / \mathrm{ha}$ of marketable roots when the water table was lowered from 15 to $45 \mathrm{~cm}$.

Yields of the Miguela cultivar increased from 1.8 to $21.4 \mathrm{t} / \mathrm{ha}$ when the water table was lowered from 15 to $45 \mathrm{~cm}$.

Yields of the Gem cultivar were significantly higher than those of the Miguela cultivar.

These results showed that the free water table must be kept at least 45 $\mathrm{cm}$ below the soil surface to obtain high yields of sweet potatoes.

\section{RESUMEN}

El efecto de tres niveles freáticos en el rendimiento de dos variedades comerciales de batatas se determinó en lisímetros que contenían un suelo Toa arcilloso lómico.

Las plantas de la cultivar Gem produjeron 6.7, 13.4 y $33.9 \mathrm{Tm} / \mathrm{ha}$, y las de la cultivar Miguela 1.8, 13.4 y $21.4 \mathrm{Tm} / \mathrm{ha}$ cuando el nivel freático se mantuvo a 15,30 y $45 \mathrm{~cm}$ de profundidad, respectivamente.

La cultivar Gem (mameya) produjo rendimientos significativamente más altos que los producidos por la cultivar Miguela (blanca).

Todas las posibles comparaciones entre tratamientos fueron altamente significativas.

Estos resultados señalan que es necesario mantener el nivel freático de los suelos sembrados de batatas a por lo menos $45 \mathrm{~cm}$ de profundidad.

\section{LITERATURE CITED}

1. Abrūna, F., Vicente-Chandler, J., Rodríguez, J., Badillo, J., and Silva, S., 1979. Crop response to soil acidity factors in Ultisols and Oxisols in Puerto Rico V. Sweet Potato, J. Argi. Univ. P.R. 63 (2): 250-67.

2. Badillo-Feliciano, J., Morales, A., and Sierra, C., 1976. Performance of white-fleshed sweet potato cultivars at two locations in Puerto Rico, J. Agri. Univ. P.R. 60 (1): 1-8.

3. - - and-1976. Performance of yellow-fleshed sweet potato cultivars at two locations in Puerto Rico, J. Agri. Univ. P.R. 60 (2): 154-62.

4. - 1976. Effect of planting season on yield of sweet potato cultivars, J. Agri. Univ. P.R. 60 (2): 163-71.

5. — and Lugo-López, M. A., 1976. Effect of four levels of N, P, K and micronutrients on sweet potato yields in an Oxisol, J. Agri. Univ. P.R. 60 (4): 597-605. 
6. - , and - , 1977. Sweet potato production in Oxisols under a high level of technology, Agri. Exp. Stn., Univ. P.R. Bull. 256.

7. Landrau, P., and Samuels, G., 1951. The effect of fertilizers on the yield and quality of sweet potatoes, J. Agri. Univ. P.R. 35 (2): 71-8.

8. Moscoso, C. G., 1955. El cultivo de la batata en Puerto Rico, Esta. Exp. Agri. Univ. P.R. Bol. 126.

9. Pérez-Escolar, R., 1977. Effect of soil pH and related acidity factors on yields of sweet potatoes and soybeans grown on typical soils of the humid tropics, J. Agri. Univ. P.R. 61 (1): 82-9.

10. Talleyrand, H. and Lugo-López, M. A., 1976. Effect of five levels and three sources of $\mathrm{N}$ on sweet potato yields on an Ultisol, J. Agri. Univ. P.R. 60 (1): 9-14. 